\title{
Socio - Economic Determinants of Girls' Performance in Agriculture in Public Mixed Day Secondary Schools of Kirinyaga Central Sub - County, Kirinyaga County, Kenya
}

\author{
${ }^{1}$ Paul Muchira Muriithi, ${ }^{2}$ Prof. John Gowland Mwangi, ${ }^{3}$ Dr. Maurice O. Udoto \\ Department of Agricultural Education and Extension, Egerton University P.O. Box 536-20115, Egerton, Kenya.
}

\begin{abstract}
For many of the world's people, agriculture is both a source of food and a means of livelihood. In Kenya, the agriculture sector has immense contribution to the economy in terms of providing food, employment and foreign exchange among other roles. Women make essential contributions to the country's agricultural and rural economy. Besides their daily routine consisting of cooking, cleaning, and other domestic chores, women are heavily involved in all aspects of the country's agricultural sector; from crop production to livestock rearing. Secondary school girls' performance in agriculture is therefore vital for it determines their future ability to engage in productive agricultural activities that would enhance food security and generate income for the family and the society at large. Unfortunately, girls in Kirinyaga Central sub - county's public mixed day secondary schools continue to perform poorly in the Kenya Certificate of Secondary Education (KCSE) agriculture examination. This study therefore aimed at investigating the extent to which parental factors, involvement in household chores, and school factors influenced girls' performance in agriculture in the sub county's public mixed day secondary schools. Target population was form three girls taking agriculture and agriculture teachers in the public mixed day secondary schools in Kirinyaga Central sub - county. Descriptive survey research design was used. Systematic random sampling technique was used to select girls for the study. Agriculture teachers were purposively sampled. Sample size included 20 teachers and 131 girls out of a population of 195 girls. Questionnaires and a standardized form three agriculture examination were used to collect data. A t-test and ANOVA at $\alpha=0.05$ were used to analyze the data. Study findings indicated that parental factors (parents / guardians' education and parental support), girls' involvement in household chores and school factors (teachers' academic qualification, teachers' experience and agriculture facilities) had a statistically significant $p \leq 0.05$ influence on girls' KCSE performance in agriculture. The study concluded that parental factors, girls' involvement in household chores and school factors are all important determinants of girls' performance in agriculture. To improve girls' performance in agriculture, the study recommended: support by the parents, reduced household chores for girls, adequate facilities for teaching agriculture, and use of agriculture teachers with higher academic qualifications and experience.
\end{abstract}

Key Words: Girls' performance in agriculture, Household chores, Parental Support, Parents' Education, Agriculture facilities, teachers' academic qualifications, Teachers' experience

\section{Introduction}

Education is vital for raising a generation of holistic individuals who are self-reliant with ability to accommodate divergent economic and social-cultural values of others in the society. According to Offorma (2009), education is a process through which the young acquires knowledge and realizes her potentialities and uses them for self-actualization, to be useful to her and others. Good quality education in terms of learning outcomes in literacy, numeracy and life skills can contribute to increased work productivity, higher individual income levels, economic and social growth, improvement in health, the generation of innovative ideas, and the rapid learning of new technology (Saito \& Cappelle, 2009). Similar sentiments were held by Nelson Mandela who observed that education is the most powerful weapon a person can use to change the world (Sichone, 2011). Needless to say, education remains the bedrock of all facets of development and no child below the age of 18 years should be elsewhere but in a school pursuing education (Agwom, 2010). Educating girls cannot be overemphasized. The old adage that if you educate a man, you educate an individual, but if you educate a woman, you educate the whole society makes a lot of sense. Children are the future leaders and mothers are the guardians of the future (Offorma, 2009). Therefore, educating girls who are mothers of tomorrow would enable the family and society at large to raise healthy and productive individuals who are physically, socially and mentally well developed. Addressing the United Nation's Fifty-Fifth Session of the Commission on the Status of Women in New York, Odinga (2011) asserted that women's active participation in education especially in science and technology would create more job opportunities. A girl without education becomes a woman vulnerable to the risks of unhealthy childbearing patterns, who is less empowered in decision making and with 
limited access to resources in both private and public spheres (Mowla, 2009). Education further empowers women to make informed decisions regarding the family planning method to adopt and the number of children to have. Women engaged in professional careers or income generating activities can ill afford the opportunity cost of having many children (Kimani \& Kombo, 2010). Indeed, according to Dawo and Simatwa (2010), girls' education reduces poverty, lower infant and maternal mortality and improves health, nutrition and environmental management. Learning agriculture in secondary schools by girls is of enormous importance. This is partly because agriculture is an important engine of economic growth and poverty reduction (Doss, Raney, Ariquenz, Croppenstedt, Gerosa, Lowder, Matuscke, \& Skoet, 2011). On the other hand, women are the backbone of the economy, comprising majority of small scale farmers in many developing countries (Verveer, 2011). Women make essential contributions to agricultural and rural economies in several countries (International Fund for Agricultural Development [IFAD], 2011). Besides their daily routine consisting of cooking, cleaning, and other domestic chores, women are heavily involved in all aspects of a country's agricultural sector; from crop production to livestock rearing (Jamali, 2009). Women continue to earn a substantial portion of the family income and continue to dominate food processing industries, and backyard livestock and vegetable production, besides taking their primary function as housekeepers and home makers (Satyavathi, Bharadwaji, \& Brahmanand, 2010). According to Verveer (2011) agriculture is central to economic growth when women learn the best way to grow and cultivate their own nutritious food which they can use to feed their children and sell excess produce in the markets. However, this is only possible when girls are provided with quality agriculture education. It is against this background that good performance of girls in secondary school agriculture is imperative. Unfortunately, girls in Kirinyaga Central sub - county's public mixed day secondary schools continue to perform poorly in KCSE agriculture examination (see appendix D). This could be partly because girls learning in public mixed day secondary schools are faced with many problems especially those from poor families (Hakijamii, 2009). Factors that have been blamed for girls' poor academic performance include student's involvement in household chores (Omenge \& Nasongo, 2010), parent's education (Ajayi \& Muriana, 2011), and parental support (George \& Mensah, 2010), among others. Studies show that the school environment which includes factors such as availability of textbooks, availability of teaching and learning facilities, and the class size could also influence student's academic performance (Juma et al., 2011; Lippman, 2010). Though with mixed results, studies also show that teacher's gender may influence the student's academic performance (Antecol, Eren, \& Ozbeklik, 2012; Beilock, Gunderson, Ramirez, \& Levine, 2010; Carrel, Marianne, \& James, 2010; Folashade, 2009; Neugebauer, Helbig, \& Landmann, 2010). This study was restricted to three factors: Parental factors (parent's education and parental support), involvement in household chores, and school factors (agricultural facilities, teacher's academic qualification and teacher's experience). Factors influencing agriculture performance have received little attention in literature. Little attention has also been given to the study of factors influencing agriculture performance of girls in public mixed day secondary schools. This study aimed at bridging this gap.

\section{Statement of the Problem}

Many girls in Kirinyaga Central sub - county's public mixed day secondary schools continue to perform poorly in KCSE agriculture examination. Their poor performance in the subject may in future translate to poor agricultural practices which may hinder the achievement of food security in the country. Influence of social economic factors on girls' performance in agriculture has not been clear. This study therefore sought to establish the socio - economic determinants of girls' performance in agriculture in Kirinyaga Central sub - county's public mixed day secondary schools.

\section{Objectives of the Study}

The study aimed at achieving the following three objectives:

(i) Determine the extent to parental factors (parents/guardians' education and parental support) influence public mixed day secondary schools girls' performance in agriculture.

(ii) Determine the extent to which involvement in household chores influence public mixed day secondary schools girls' performance in agriculture.

(iii) Determine the extent to which school factors (agriculture facilities, teachers' academic qualifications and teachers' experience) influence public mixed day secondary schools girls' performance in agriculture.

\section{Hypothesis}

The study was guided by the following hypothesis:

$\mathbf{H o}_{1}$ : Parental factors have no statistically significant influence on girls' performance in agriculture in Kirinyaga Central Sub - County's public mixed day secondary schools. 
Ho$_{2}$ : Involvement in household chores has no statistically significant influence on girls' performance in agriculture in Kirinyaga Central Sub - County's public mixed day secondary schools.

$\mathbf{H o}_{3}$ : School factors have no statistically significant influence on girls' performance in agriculture in Kirinyaga Central Sub - County's public mixed day secondary schools.

\section{Theoretical Framework}

The study was informed by two theories: Bandura's Social Cognitive Theory and the Education Production Function Theory.

\section{Bandura's Social Cognitive Theory}

This theory posits that people learn from one another, via observation, imitation and modeling (Bandura, 2006). It explains human behavior in terms of continuous reciprocal interaction between cognitive, behavioral and environmental influences (Cunningham, 2009). Behaviorism essentially states that one's environment causes one's behavior. In this respect, home environment in terms of parent's education level and parental support would influence the behavior of the girls in terms of effort towards academic tasks which would further impact positively on her performance in agriculture. A home environment where a girl is faced with several household chores would reduce the student's time spent on academic work thus impacting negatively on her effort and performance in agriculture. Based on environmental influence, the theory further suggests that educated parents are more likely to employ strategies that support their children's learning. Thus, girls' from a home environment where the parents are educated would receive necessary parental support and therefore perform better in agriculture. Similarly, a school environment having necessary facilities for teaching and learning agriculture and qualified and experienced agriculture teachers would help improve girls' performance in agriculture.

\section{Education Production Function Theory}

An education production function is an application of the economic concept of a production function to the field of education. It relates to various inputs affecting students' learning, such as schools, families, peers and neighborhoods, to outputs including subsequent labour market success, college attendance, graduation rates and most frequently, standardized test scores. Education production function theory has its foundation on the United States' 1966 Coleman Report on Equality of Education Opportunity (Coleman et al., 1966) which found that student's background and socio - economic status are much more important in determining educational outcomes than are measured differences in school resources per pupil spending. Ideally, the environment both at home and school will either support girls' proper learning of agriculture or not. On the basis of this theory, parental factors, involvement in household chores, and school factors are important education production factors assumed to determine Kirinyaga Central sub - county's public mixed day secondary schools girls' performance in agriculture. It was expected that girls whose parents are educated and who offer them good support in their education would have better performance in agriculture than girls whose parents are illiterate and who offer them little or no support. Involvement in household chores is a factor that was expected to affect girls' performance in agriculture negatively. It was also expected that availability and adequacy of agricultural facilities and presence of experienced and qualified agriculture teachers would lead to better girls' performance in agriculture.

\section{Location of the Study}

The study was carried out in all public mixed day secondary schools in Kirinyaga Central sub - county, Kirinyaga County. The large number of public mixed day secondary schools in the sub - county compared to other sub - counties in Kirinyaga County favored the study. Mixed small scale farming is the major economic activity in the sub - county. The sub - county has a tea zone in the north and a coffee zone in the south. It has its headquarters as Kutus town. Other important towns in the sub - county are Kagumo in the tea zone and Kerugoya in the coffee zone. The sub - county covers an area of $173.6 \mathrm{~km}^{2}$ with a population of 113,355 persons; hence a population density of approximately 653 persons per square kilometre. The sub - county borders Mt. Kenya forest to the north and is well served by permanent water sources such as Thiba, Ciaminogia, Rundu and Rutui rivers; besides having several springs such as Kiwe and Kagumba. Other important features in the sub -county include Kamuruana hill, Kangaita tea factory and Mununga tea factory. The sub - county has relatively good road network connecting other towns with its headquarters, Kutus town. Important roads include Kutus - Kerugoya-Kagumo-Karatina and Kutu-Kagio-Sagana-Nairobi roads. 


\section{Research Methodology}

Descriptive survey design was used in this study. According to Shilubane (2009), a survey is used to collect original data for describing a population too large to observe directly. It obtains information about a particular issue from a sample of people by means of self- report, that is, the people respond to a series of questions posed by the investigator (Mugenda, 1999). This design was considered appropriate for the study because it provides an accurate account of the characteristics being studied. It therefore met the objectives of determining the extent to which parental factors, involvement in household chores and school factors influence girls' performance in agriculture in Kirinyaga Central sub - county's public mixed day secondary schools. Advantages of using the survey design also included the ability to accommodate a large sample size's generalizability of results, ease of administering questions and recording answers and increased capability of using advanced statistical analysis (The McGraw-Hill Companies, 2001). The target population was form three and four girls taking agriculture and agriculture teachers. The accessible population, however, constituted form three girls taking agriculture and their agriculture teachers. Form three girls were selected for the study because they had done subject selection which is normally done at the end of form two. Form four girls taking agriculture were not involved in the study because they were busy preparing for their KCSE and thus were unavailable for the research process. All the 20 Kirinyaga Central sub - county's public mixed day secondary schools were involved in the study. Systematic random sampling was used to select the form three girls that participated in the study. In this method of sampling all the form three girls from the 20 public mixed day secondary schools were listed down to form the sampling frame using class lists. This listing formed the population of girls from which respondents were sampled. A total of 131 girls were selected from a population of 195 girls (Appendix E) at a 0.05 margin of error; using the formula developed by Israel (2009) below:

$\begin{array}{cll}\text { Where } \mathrm{n} & = & \text { Sample size } \\ \mathrm{N} & = & \text { Population and } \\ \mathrm{e} & = & \text { Margin of error }\end{array}$

$$
n=\frac{N}{1+N(e)^{2}}
$$

This formula was appropriate for determining the sample for the study because it gives a good sample size that lead to accurate results. A sample size obtained through the formula is neither too small leading to inaccurate results nor too large leading to wastage of time, resources and money. Purposive sampling was used to select 20 agriculture teachers. Data was collected using researcher - developed questionnaires and a standardized form three agriculture examination. The researcher developed a Likert scale for most of the questionnaire items for easy analysis of data. There was a students' and a teachers' questionnaire. Students' questionnaire had two sections. Section A sought information on parental factors while section B sought information on girls' involvement in household chores. Section A of the students' questionnaire had 14 items; 2 items sought information on the demographic characteristics of girls' parents or guardians, 1 item on parents/guardians' education and 11 items sought information on parental support. Section B of the students' questionnaire had 5 items that sought information on girls' involvement in household chores. Teachers' questionnaire sought information on school factors. It had two sections, A and B. Section A had 3 items and sought information on teachers' gender, academic qualifications and teaching experience. Section B had 4 items that sought information on availability and adequacy of facilities for teaching and learning agriculture, that is, school farm or agriculture demonstration plots, farm tools and equipment, agriculture text books and farm structures. An index based on the questionnaire items was developed and tested against students' scores on the standardized examination. Validity refers to the degree that an instrument actually measures what it is designed to measure (Burton \& Mazerolle, 2011). Two types of validity were considered in this study, namely, face validity and content validity. Face validity is an evaluation of an instrument's appearance with the aim of establishing the instrument's ease of use and clarity while content validity is the evaluation of an instrument's representativeness of the topic to be studied (Burton \& Mazerolle, 2011) so as to establish its credibility, accuracy, relevance, and breadth of knowledge regarding the domain. Face and content validity were established by a panel of three experts who judged the instrument's appearance and representativeness of the topic studied (Netemeyer, Bearden, \& Sharma, 2003; Turocy, 2002).

Reliability refers to the consistency of a test or measurement (Burton \& Mazerolle, 2011). It concerns the extent to which the instrument yields the same results on repeated trials. It was estimated by use of Cronbach's alpha reliability coefficient for Likert - type scales. According to Gliem and Gliem (2003) Cronbach's alpha is a test reliability technique that requires only a single test administration to provide a unique estimate of the reliability for a given test. It is an internal consistency index designed for use with tests containing items that have no right answer (Key, 1997); as was the case in this study. In addition, the instruments used in this study had multiple items, and as such, Cronbach's alpha internal consistency reliability could be calculated. A minimum of 0.7 Cronbach's alpha reliability coefficient was to be accepted for the study. Pilot testing the data collection instruments was done to enhance their reliability. According to Kathuri and Pals 
(1993), a sample of twenty five to fifty respondents is good for pilot testing. In this study, twenty five form three girls taking agriculture from one public mixed day secondary school in the neighboring Kirinyaga West sub county were sampled for the pilot test. Data collection commenced immediately the researcher obtained the University's approval. The researcher first sought a research permit from the National Council of Science, Technology and Innovation (NCSTI) to conduct research in public mixed day secondary schools in Kirinyaga Central sub - county. He further sought permission from Kirinyaga Central sub - county's commissioner and education officer to conduct the research. Sampled schools were visited to inform the principals about the study and discuss the logistics of data collection. Both the students' and teachers' questionnaires were administered by the researcher. The respondents were given the questionnaires to complete after which the researcher collected them after one week. The standardized examination was set by a panel of three agriculture teachers. The panel constituted teachers who usually set Kirinyaga Central sub - county Joint Agriculture Examinations. The examination was administered by agriculture teachers in respective schools and marked by the same teachers using a standard marking scheme. The examination, which took two hours, was done at the same time in all schools. Descriptive and inferential statistics were used to analyze the data at $95 \%$ confidence level $(\alpha=0.05)$ using the Statistical Package for Social Scientists (SPSS version 22). In descriptive statistics the data was analysed using measures of central tendency (means, median and mode), frequency distributions and percentages. The inferential statistics used to test the influence of the independent variables on the dependent variable were the $t$-test and the analysis of variance (ANOVA).

\section{Demographic Characteristics of the Respondents}

\section{Results and Discussion}

The type of parentage and parents' / guardians' occupational status were deemed important in this study as both may impact on parental support and girls' involvement in household chores; both of which may influence girls' performance in agriculture. The table 1 shows the frequency distribution of the respondents' type of parentage while Table 2 shows the frequency distribution of the parents' / guardians' occupation. The majority of the girls $(87.8 \%$ ) came from families that had both parents / guardians. Girls who had the female parent / guardian only were $10.7 \%$ while those who had a male parent /guardian only were $1.5 \%$ of the total number of respondents. On the other hand, eleven different types of occupation were identified by the respondents. These included small scale farming, casual labour, business, carpentry, tailoring, driving, civil service, teaching, policing, nursing, and secretarial work. Three types of occupation formed the major ones out of the eleven identified; they were small - scale farming $(47.5 \%)$, casual laborer $(23.3 \%)$ and business (18.2 $\%)$. These occupations are a reflection of the major activities undertaken by the people in the study area.

Table 1: Type of Parentage

\begin{tabular}{lll}
\hline Type of Parentage Present & Frequency & Percent \\
\hline Both Male and Female Parents / Guardians & 115 & 87.8 \\
Only Female Parent / Guardian & 14 & 10.7 \\
Only Male Parent / Guardian & 2 & 1.5 \\
\hline Total & $\mathbf{1 3 1}$ & $\mathbf{1 0 0 . 0}$ \\
\hline
\end{tabular}

Table 2: Occupation of the Parents / Guardians $(n=131)$

\begin{tabular}{|c|c|c|c|c|c|c|}
\hline \multirow[b]{2}{*}{ Occupation } & \multicolumn{2}{|c|}{ Male Parent / Guardian } & \multicolumn{2}{|c|}{$\begin{array}{l}\text { Female } \\
\text { Guardian }\end{array}$} & \multicolumn{2}{|c|}{ Total } \\
\hline & $\mathbf{F}$ & $(\%)$ & $\mathbf{F}$ & $(\%)$ & $\mathbf{F}$ & $(\%)$ \\
\hline Small-scale Farmer & 57 & 48.7 & 58 & 45.0 & 115 & 47.5 \\
\hline Casual Labourer & 21 & 17.9 & 37 & 28.7 & 58 & 23.3 \\
\hline Businessman / woman & 19 & 16.3 & 26 & 20.0 & 45 & 18.2 \\
\hline Carpenter & 7 & 5.9 & 0 & 0.0 & 7 & 2.6 \\
\hline Tailor & 3 & 2.6 & 3 & 2.3 & 6 & 2.4 \\
\hline Driver & 5 & 4.3 & 0 & 0.0 & 5 & 2.0 \\
\hline Civil Servant & 2 & 1.7 & 2 & 1.6 & 4 & 1.5 \\
\hline Teacher & 1 & 0.9 & 1 & 0.8 & 2 & 0.8 \\
\hline Police & 2 & 1.7 & 0 & 0.0 & 2 & 0.8 \\
\hline Nurse & 0 & 0.0 & 1 & 0.8 & 1 & 0.4 \\
\hline Secretary & 0 & 0.0 & 1 & 0.8 & 1 & 0.4 \\
\hline Total & 117 & 100.0 & 129 & 100.0 & 246 & 100.0 \\
\hline
\end{tabular}

\section{Results on Parental Factors}

The level of education of the parents was considered to be an important independent factor that would influence the performance of the girls in the field of agriculture. The girls were asked to state the highest level of education that their parents/guardians had attained. The responses were grouped into five categories, as follows: the ones whose education level was below standard eight, the group that only managed to complete standard 
eight or primary school, the category that had completed form four or secondary school level, the group that progressed beyond secondary school and obtained a college diploma and the group that obtained a university degree. The frequency distribution of the girl's responses on their parents/guardians' education level is given in Table 3.

Table 3: Distribution of the Education Levels of Parents/Guardians

\begin{tabular}{llll}
\hline Level of Education & Frequency & Percent & Girls' Mean Marks \\
\hline Below standard eight & 20 & 15.3 & 19.5 \\
Standard eight level (primary) & 39 & 29.8 & 37.2 \\
Secondary & 61 & 46.6 & 55.8 \\
Diploma & 9 & 6.9 & 70.0 \\
Degree & 2 & 1.5 & 68.0 \\
\hline Total & $\mathbf{1 3 1}$ & $\mathbf{1 0 0 . 0}$ & \\
\hline
\end{tabular}

The results shown in Table 3 indicate that the proportion of girls whose parents / guardians had primary level of education and below formed $45.1 \%$. While a big proportion of the respondents $(46.6 \%)$ indicated that their parents / guardians had attained the secondary school level of education, the results indicate that few of those parents were able to progress to tertiary institutions for diploma and degree studies. The results also showed that the higher the education of the parents / guardians, the higher the girls' mean marks. For instance, girls whose parents / guardians had diploma and bachelor degree levels of education obtained mean marks of 68 and above while girls whose parents / guardians had primary and below primary levels of education obtained mean marks of 37.2 and below. Parental support was the second parental factor considered to be an important socio economic determinant of girls' performance in agriculture. To help assess the level of parental support, the respondents were required to respond to eleven statements that formed the indicators of parental support. The eleven statements sought information on whether the parent / guardian guide her when faced with school related problems, provide her with personal effects, provide her with a conducive home environment for learning agriculture, is concerned about her score in agriculture tests, guide her in agriculture, go to school to discuss her studies with teachers, encourage her to work hard in agriculture, monitor her when doing studies at home, provide her with agriculture learning materials, emphasize to her the value of education, and, emphasize to her the need to pass well in agriculture. The 11 indicators of parental support were rated by the respondents on a five point Likert scale $(1=$ strongly disagree indicating the lowest level of parental support, $2=$ disagree, $3=$ moderately agree, $4=$ agree, and, $5=$ strongly agree indicating the highest level of support by the parent). The numbers on the Likert scale for the 11 items were added to obtain a scale ranging from 11 to 55 which was then put in categories that defined the five different levels of parental support. Table 4 shows how the 131 respondents rated each of the eleven indicators of parental support on the Likert scale while table 5 shows the frequency distribution of the different levels of parental support. From the results shown in Table $5,42 \%$ of the respondents received low to moderate support from their parents / guardians while $58 \%$ of the respondents received high to very high parental support. The mean marks of the respondents varied with the different levels of parental support; with girls who received the lowest support scoring lowest in their agriculture examination while girls who received more support from their parents / guardians scored higher marks in their agriculture examination.

Table 4: Girls' Rating of Indicators of Parental Support

\begin{tabular}{|c|c|c|c|c|c|}
\hline Parent Support Factors & $\begin{array}{l}\text { Very Low } \\
(\%)\end{array}$ & $\begin{array}{l}\text { Low } \\
(\%)\end{array}$ & $\begin{array}{l}\text { Moderate } \\
(\%)\end{array}$ & $\begin{array}{l}\text { High } \\
(\%)\end{array}$ & $\begin{array}{l}\text { Very High } \\
(\%)\end{array}$ \\
\hline Guidance on school problems & 0.0 & 0.8 & 11.5 & 38.2 & 49.6 \\
\hline Provision of personal effects & 0.0 & 0.0 & 9.2 & 7.6 & 83.2 \\
\hline Conducive home environment & 3.1 & 3.1 & 12.2 & 35.9 & 45.8 \\
\hline Scores obtained in agriculture & 3.1 & 9.9 & 14.5 & 36.6 & 35.9 \\
\hline Guidance in agriculture & 7.6 & 22.9 & 9.9 & 24.4 & 35.1 \\
\hline Discussion with girls' teacher & 8.4 & 23.7 & 22.9 & 27.5 & 17.6 \\
\hline Encouraged to work hard & 0.0 & 3.1 & 3.8 & 33.6 & 59.5 \\
\hline Monitoring girls' studies at home & 3.1 & 4.6 & 15.3 & 34.4 & 42.7 \\
\hline Agriculture learning materials & 12.2 & 22.9 & 22.9 & 30.5 & 11.5 \\
\hline Emphasis on value of Education & 0.0 & 0.8 & 1.5 & 26.0 & 71.8 \\
\hline Need to pass well in agriculture & 0.0 & 7.6 & 9.9 & 42.7 & 39.7 \\
\hline
\end{tabular}


Table 5: Distribution of Levels of Parental Support

\begin{tabular}{lllll}
\hline Category & Level of support & Frequency & Percent & Girls' Mean Marks \\
\hline $11-21$ & Low & 4 & 3.1 & 24.3 \\
$22-32$ & Moderate & 51 & 38.9 & 45.1 \\
$33-43$ & High & 74 & 56.5 & 47.6 \\
Above 43 & Very high & 2 & 1.5 & 62.0 \\
\hline Total & & $\mathbf{1 3 1}$ & $\mathbf{1 0 0}$ \\
\hline
\end{tabular}

\section{Results on Involvement in Household Chores}

The variable involvement in household chores was operationalized by asking the respondents to rate four different statements used as indicators of involvement in household chores. In the four statements, the respondents were required to rate the extent of engagement in household chores before school, after school, during weekend, and, their perception on the extent to which they were engaged in household chores. The responses to the four statements were rated on a five point Likert scale (1=strongly disagree indicating the lowest level of engagement, $2=$ disagree, $3=$ moderately agree, $4=$ agree, and $5=$ strongly agree indicating the highest level of involvement in household chores). The numbers on the Likert scale for the four items were added to obtain a scale ranging from 4 to 20 which was then put in categories that defined the five different levels of involvement in household chores. The Table 6 shows how the 131 respondents rated each of the four indicators of involvement in household chores while Table 7 shows the frequency distribution of the different levels of involvement in household chores as an aggregated variable.

Table 6: Girls' Rating of the Indicators of Involvement in Household Chores

\begin{tabular}{|c|c|c|c|c|c|c|}
\hline Girls Involvement in Household Chores & $\begin{array}{l}\text { Very Low } \\
(\%)\end{array}$ & $\begin{array}{l}\text { Low } \\
(\%)\end{array}$ & $\begin{array}{l}\text { Moderate } \\
(\%)\end{array}$ & $\begin{array}{l}\text { High } \\
(\%)\end{array}$ & $\begin{array}{l}\text { Very } \\
(\%)\end{array}$ & High \\
\hline Engagement Before school & 79.4 & 3.8 & 3.1 & 1.5 & 12.2 & \\
\hline Engagement After School & 9.9 & 10.7 & 7.6 & 1.5 & 70.2 & \\
\hline Engagement during Weekends & 19.1 & 19.1 & 37.4 & 0 & 24.4 & \\
\hline Time spent on Chores & 7.6 & 20.6 & 26.0 & 20.6 & 25.2 & \\
\hline
\end{tabular}
$\mathbf{n}=\mathbf{1 3 1}$

The results on Table 6 show that most of the girls $(71.7 \%)$ spent more time on household chores after school in the evening than before going to school in the morning $(13.7 \%)$. The results also show that a large proportion $(45.8 \%)$ of the girls felt that they spent a lot of their time carrying out household chores; time which they would have spent reading. Such girls would not be expected to perform as well in agriculture as those girls who felt that they didn't spend as much of their time carrying out household chores $(28.2 \%)$.

Table 7: Distribution of the Levels of Involvement in Household Chores

\begin{tabular}{lllll}
\hline Category & Level of Involvement & Frequency & Percent & Girls' Mean Marks \\
\hline Below 6 & Very low & 4 & 3.1 & 55.0 \\
$6-9$ & Low & 17 & 13.0 & 54.5 \\
$10-13$ & Medium & 35 & 26.7 & 49.6 \\
$14-17$ & High & 51 & 38.9 & 42.5 \\
Above 17 & Very High & 24 & 18.3 & 41.2 \\
\hline Total & & $\mathbf{1 3 1}$ & $\mathbf{1 0 0 . 0}$ &
\end{tabular}

From the results shown in Table 7 , it is clear that majority of the respondents $(57.2 \%)$ had high to very high level of involvement in household chores while only $16.1 \%$ of them reported to have very low to low level of involvement. The results also show that the girls' mean marks varied with the level of involvement in household chores; with girls having very low level of involvement in household chores obtaining the highest mean marks (55) and girls having very high level of involvement in household chores obtaining the lowest mean marks (41.2).

\section{Results on School Factors}

The variable agriculture facilities was operationalised by asking the respondents to indicate the extent to which their school farm / demonstration plots, farm tools and equipment, agriculture text books, and, farm structures were adequate for teaching and learning agriculture. The respondents were required to assess the adequacy of each of the four facilities based on a 5 point Likert scale. Scores on the Likert scale for the four different agriculture facilities were added together to form a scale that ranged from 4 to 20 which was then divided into two categories; one that defined the agriculture facilities as of low adequacy (4 - 12) and the other that defined them as of high adequacy $(13-20)$. The frequency distribution of the two categories is given in Table 8 . 
Table 8: Distribution of the Level of Adequacy of Agriculture Facilities

\begin{tabular}{lllll}
\hline Category & Level of Adequacy & Frequency & Percent & Girls' Mean Marks \\
\hline $4-12$ & Low adequacy & 77 & 58.8 & 44.6623 \\
$13-20$ & High adequacy & 54 & 41.2 & 48.2222 \\
\hline Total & & $\mathbf{1 3 1}$ & $\mathbf{1 0 0 . 0}$ & \\
\hline
\end{tabular}

From the results in Table 8 , the majority $(58.8 \%)$ of the schools in the study were found to be having low adequacy of agriculture facilities. This meant that the schools lacked adequate school farm / demonstration plots, farm tools and equipment, agriculture text books and farm structures; which are all important facilities for teaching and learning agriculture. The results show that there is a relationship between the level of adequacy of the facilities and the girls' mean marks in agriculture; with girls from schools with a high level of adequacy scoring higher mean marks (48.2222) than girls from schools having low adequacy of the agriculture facilities (44.6623). The teacher's academic qualification was one of the teacher characteristics that were investigated in this study in relation to its influence on the girls' performance in agriculture. The variable teacher academic qualification was defined as the highest level of academic training in agriculture the teacher had received. The teachers were asked to indicate the highest level of academic training they had obtained. In this study three levels of academic training were identified: untrained teacher with KCSE certificate only (commonly referred to as peer teachers), teachers trained to the diploma level, and, teachers trained to the degree level. The frequency distribution of the teachers' level of training in agriculture is given in Table 9.

Table 9: Distribution of the Teachers' Academic Qualification

\begin{tabular}{llll}
\hline Level of Education & Frequency & Percent & Girls' Mean Marks \\
\hline Peer teachers / KCSE & 20 & 15.3 & 33.57 \\
Diploma & 28 & 21.4 & 37.16 \\
Bachelor Degree & 83 & 63.4 & 48.48 \\
\hline Total & $\mathbf{1 3 1}$ & $\mathbf{1 0 0 . 0}$ & \\
\hline
\end{tabular}

The majority of the teachers $(63.4 \%)$ were found to be trained to the degree level, while $21.4 \%$ of them were trained to the diploma level and the remaining $15.3 \%$ were peer teachers having only a KCSE certificate. The results indicated that the teachers' level of academic training correlated with their students' performance in agriculture. Girls taught by teachers that were educated up to the bachelor degree level were found to obtain a higher mean mark in agriculture (48.48) than girls that were taught by diploma holder teachers (37.16) and peer teachers (33.57). Teachers' experience was operationalised as the number of years the teachers had been teaching agriculture in secondary schools. There were five categories of teachers' experience; below 3 years, 4 to 6 years, 7 to 9 years, 10 to 12 years, and, 13 years and above. The teachers' experience frequency distribution is given in Table 10 .

Table 10: Distribution of the Teachers' Experience

\begin{tabular}{llll}
\hline $\begin{array}{l}\text { Category } \\
\text { (Years) }\end{array}$ & Frequency & Percent & Girls' Mean Marks \\
\hline Below 3 & 3 & 2.3 & 25.6 \\
4 to 6 & 6 & 4.6 & 33.5 \\
7 to 9 & 10 & 7.6 & 42.3 \\
10 to 12 & 44 & 33.6 & 43.1 \\
13 and Above & 68 & 51.9 & 50.6 \\
\hline Total & $\mathbf{1 3 1}$ & $\mathbf{1 0 0 . 0}$ & \\
\hline
\end{tabular}

The results on Table 10 indicate that majority of the agriculture teachers (85.5\%) in Kirinyaga Central sub county were experienced in teaching agriculture, having worked for more than 10 years. The teachers who had worked for less than 3 years were few amounting to $2.3 \%$ of the teachers, while the teachers who had worked for an average of five years (between 4 and 9 years) were $12.2 \%$. The results also show that the girls' mean marks in agriculture are related to their teachers' experience in teaching the subject. For example, girls who scored the highest mean marks of 50.6 had teachers whose experience in teaching was the highest (13 years and above).

\section{Results on Girls' Performance in Agriculture}

The variable girls' performance in agriculture was measured as scores obtained by the girls in a standardised agriculture examination (Appendix F) for form three in the first term of 2013 academic year. The two hour examination was administered as a mid - term assessment paper and was marked based on the standardised marking scheme (Appendix G). The maximum score for each girl in the standardised examination was 80 marks. The marks were put into five categories and ranked as Very Good (67 - 80 marks), Good (50 - 66 
marks), Average (34 - 49 marks), Below Average (17 - 33 marks) and Poor (11 - 16marks). The frequency distribution of the scores obtained by the girls in the examination is given in Table 11.

Table 11: Frequency Distribution of the Girls' Scores on the Standardised Examination

\begin{tabular}{clll}
\hline Marks & Category & Frequency & Percent \\
\hline $0-16$ & Poor & 9 & 6.9 \\
$17-33$ & Below Average & 20 & 15.3 \\
$34-49$ & Average & 44 & 33.6 \\
$50-66$ & Good & 35 & 26.7 \\
$67-80$ & Very Good & 23 & 17.6 \\
\hline Total & & $\mathbf{1 3 1}$ & $\mathbf{1 0 0 . 0}$ \\
\hline
\end{tabular}

Mean 46.12, Std. dev. 17.31

The results on the girls' performance on the standardized agriculture examination show that majority of the girls $(33.6 \%)$ were in the average performance category. This means that there could be certain factors hindering majority of the girls from having outstanding performance in agriculture. These factors may include the girls' involvement in household chores, lack of adequate parental support, inadequate agriculture facilities, low teacher qualification, and little teacher experience.

\section{Influence of Parental Factors on Girls' Performance in Agriculture}

The influence of parental factors on the girls' performance in agriculture was assessed by testing the first hypothesis of this study which was stated as "parental factors (parents' / guardians' education and parental support) have no statistically significant influence on girls' performance in agriculture in Kirinyaga Central sub - county's public mixed day secondary schools".

The 5 levels of parents' / guardians' education (Table 3) were tested to determine their influence on the performance of the girls in agriculture. The analysis of variance and the Tukey's HSD were used to test the mean differences of the 5 education levels of the parents / guardians influence on the girls' performance. The analysis of variance results showing the differences in the performance of the girls grouped by their parent's education level are given in Table 12 and the post-hoc test to show the group differences is given in Table 13.

Table 12: ANOVA of the Girls' Performance by the Education Level of the Parents (n=131)

\begin{tabular}{llllll}
\hline $\begin{array}{l}\text { Source of } \\
\text { Variance }\end{array}$ & $\begin{array}{l}\text { Sum of } \\
\text { Squares }\end{array}$ & $d f$ & $\begin{array}{l}\text { Mean } \\
\text { Square }\end{array}$ & F-value & $p$-value \\
\hline Between Groups & 27740.370 & 4 & 6935.092 & 77.643 & 0.000 \\
Within Groups & 11254.424 & 126 & 89.321 & & \\
\hline Total & 38994.794 & 130 & & & \\
\hline
\end{tabular}

The ANOVA results show that differences in the performance of the girls existed by the parents / guardian groups that were based on the level of their education and these differences were statistically significant with a $p$ - value of $0.00 ;(p \leq 0.05)$; Table 12. The education level of the parents / guardians therefore had a statistically significant influence on the girls' performance in agriculture.

Table 13: Multiple Range Test (Tukey's HSD Procedure) $(\mathbf{n}=131)$

\begin{tabular}{|c|c|c|c|c|c|c|c|}
\hline $\begin{array}{l}\text { Parent / Guardian } \\
\text { Education Level }\end{array}$ & & Mean Marks & B8 & PR & SE & Dip & DE \\
\hline Below Standard 8 & (B8) & 19.5 & & & & & $*$ \\
\hline Primary & (PR) & 37.2 & & & & & $*$ \\
\hline Secondary & (SE) & 55.8 & & & & & * \\
\hline Diploma & (Dip) & 70.0 & & & & & \\
\hline Degree & (DE) & 68.0 & * & $*$ & * & & \\
\hline
\end{tabular}

The mean marks for girls whose parents / guardians had attained the college and degree level of education were the highest; being 70 and 68 marks respectively (Table 13). Girls whose parents / guardians had below standard 8 education level had the lowest mean marks. The 4 levels of parental support; low, moderate, high and very high (Table 5) were tested to determine their influence on the performance of the girls in agriculture. The analysis of variance and the Tukey's HSD were used to test the mean differences of the 4 levels of the parental support influence on the performance of the girls in agriculture. The ANOVA results showing the differences in the performance of the girls grouped by their parents / guardians' levels of support are given in Table 14 and the post-hoc test to determine the group differences is given in Table 15.

Table 14: ANOVA of the Girls' Performance by the Levels of Parental Support (n=131)

\begin{tabular}{lllll}
\hline $\begin{array}{l}\text { Source of } \\
\text { Variance }\end{array}$ & $\begin{array}{l}\text { Sum of } \\
\text { Squares }\end{array}$ & Df & $\begin{array}{l}\text { Mean } \\
\text { Square }\end{array}$ & F-value \\
\hline Between Groups & 2636.722 & 3 & 878.907 & 3.070 \\
Within Groups & 36358.071 & 127 & 286.284 & 0.030 \\
Total & 38994.794 & 130 & & \\
\hline
\end{tabular}


Table 15: Multiple Range Test (Tukey's HSD procedure) $(\mathrm{n}=131)$

\begin{tabular}{|c|c|c|c|c|c|c|c|c|}
\hline $\begin{array}{l}\text { Level of } \\
\text { Support }\end{array}$ & & $\mathbf{N}$ & Mean Marks & VL & $\mathbf{L}$ & M & $\mathbf{H}$ & VH \\
\hline Low & $\mathrm{L}$ & 4 & 24.3 & & & & & $*$ \\
\hline High & $\mathrm{H}$ & 74 & 47.6 & & & & & \\
\hline Very high & $\mathrm{VH}$ & 2 & 62.0 & $*$ & $*$ & * & & \\
\hline
\end{tabular}

*means are significantly different at $p \leq 0.05$

The ANOVA results (Table 14) indicate that parental support had a statistically significant influence on the girls' performance at a $p$ - value of $0.030 ;(p \leq 0.05)$. The results of the mean separation done using the Tukey's HSD (Table 15) show that the mean marks of the girls whose parents gave them a lot of support was higher (62.0 marks) than the mean marks of the girls whose parents gave them low support ( 24.3 marks) and this difference in mean marks was statistically significant at $p \leq 0.05$. Overall, parental factors (parents / guardians' education and parental support) were therefore found to have a statistically significant influence on girls' performance in agriculture in Kirinyaga Central sub - county's public mixed day secondary schools and therefore the null hypothesis was rejected. Parents with a higher level of education had daughters who performed better in agriculture than parents who had low levels of education. The educated parents / guardians could generally be employed earning a salary and therefore able to meet the basic needs of their children (Muola, 2010). The same parents / guardians could also be able to provide their children with a good learning environment at home (Chevalier et al., 2010), conditions that would enhance the higher performance. Parental support, on the other hand, is therefore a strong predictor of girls' performance in agriculture. This is consistent with the findings by Atta and Jamil (2012) who, in their study to investigate the effects of motivation and parental influence on the educational attainments of students at secondary school level found that children with close and caring parents who would encourage them and participate in their educational activities have better academic performance. Girls therefore need parental support in terms of tender care, love and provision of basic needs and regular encouragement to pass well in agriculture as confirmed by the results of this study.

\section{Influence of Household Chores on Girls' Performance in Agriculture}

The influence of involvement in household chores on girls' performance in agriculture was tested against the second hypothesis of this study which was stated as "Involvement in household chores has no statistically significant influence on girls' performance in agriculture in Kirinyaga Central sub - county's public mixed day secondary schools'. The hypothesis was tested using the analysis of variance. The different mean marks obtained by girls in each category of level of involvement in household chores (Table 7) were compared using ANOVA (Table 16). The results of the ANOVA shown in Table 16 indicate that involvement in household chores had a statistically significant influence on the girls' performance in agriculture at $p$ - value of $0.029 ;(p \leq$ 0.05). The mean separation was done using the Tukey's HSD and the results (Table 17) shows that the mean marks of the girls who had high involvement in household chores was lower (41.2 marks) compared to that of girls who had low involvement in household chores (55.0 marks). This difference in the mean marks was found to be statistically significant at $p \leq 0.05$.

Table 16: ANOVA of Girls' Performance by the Levels of Involvement in Household Chores $(\mathbf{n}=131)$

\begin{tabular}{llllll}
\hline $\begin{array}{l}\text { Source of } \\
\text { variance }\end{array}$ & $\begin{array}{l}\text { Sum of } \\
\text { Squares }\end{array}$ & Df & $\begin{array}{l}\text { Mean } \\
\text { Square }\end{array}$ & F-value & p-value \\
\hline Between Groups & 3182.573 & 4 & 795.643 & 2.799 \\
Within Groups & 35812.221 & 126 & 284.224 & & 0.029 \\
Total & 38994.794 & 130 & & \\
\hline
\end{tabular}

Table 17: Multiple Range Test (Tukey's HSD Procedure) $(\mathrm{n}=131)$

\begin{tabular}{lllllll}
\hline $\begin{array}{l}\text { Level of involvement in household } \\
\text { chores }\end{array}$ & & Mean marks & VL & L & M & H \\
\hline Very low & VL & 55.0 & & & \\
Low & L & 54.5 & & & $*$ \\
Medium & M & 49.6 & & & $*$ \\
High & H & 42.5 & & & $*$ \\
Very high & VH & 41.2 & $*$ & $*$ & $*$ & $*$ \\
\hline
\end{tabular}

*means are significantly different at $p \leq 0.05$

The involvement in household chores by the girls was found to have a statistically significant influence on their performance in agriculture and therefore the null hypothesis was rejected. Varied household chores coupled with high frequency of engagement would affect girls' performance in agriculture. Consistent with Juma et al. (2011), girls involved in the study were found to engage in household chores such as baby sitting, fetching 
Table 21: Mean Marks for Different Levels of Teachers' Experience $(n=131)$

\begin{tabular}{llllll}
\hline $\begin{array}{l}\text { Source of } \\
\text { Variance }\end{array}$ & $\begin{array}{l}\text { Sum of } \\
\text { Squares }\end{array}$ & df & $\begin{array}{l}\text { Mean } \\
\text { Square }\end{array}$ & F-value & p-value \\
\hline Between Groups & 4156.875 & 4 & 1039.219 & 3.759 \\
Within Groups & 34837.919 & 126 & 276.491 & 0.006 \\
\hline Total & $\mathbf{3 8 9 9 4 . 7 9 4}$ & $\mathbf{1 3 0}$ & & \\
\hline
\end{tabular}

Table 22: Multiple Range Test (Tukey's HSD Procedure) $(n=131)$

\begin{tabular}{llllll}
\hline $\begin{array}{l}\text { Teachers experience } \\
\text { (years) }\end{array}$ & $\mathbf{N}$ & $\begin{array}{l}\text { Mean } \\
\text { Marks }\end{array}$ & $\mathbf{1}$ & $\mathbf{2}$ & $\mathbf{3}$ \\
\hline Below 3 & 3 & 25.6 & & & \\
4to 6 & 6 & 33.5 & & & \\
7 to 9 & 10 & 42.3 & & $*$ & $*$ \\
10 to 12 & 44 & 43.1 & $*$ & $*$ \\
13 and Above & 68 & 50.6 & & \\
\hline Total & $\mathbf{1 3 1}$ &
\end{tabular}

*means are significantly different at $p \leq 0.05$

The results of the ANOVA given in Table 21 indicate that teachers' experience had a statistically significant influence on the girls' performance in agriculture with a $p$ - value of $0.006 ;(p \leq 0.05)$. The results of the mean separation show that the mean marks of the girls who were taught by the teachers who had more than 13 years of experience was higher (50.6 marks) than that of the girls who were taught by teachers with lower experience. The differences in the mean marks obtained at the various levels of teachers' experience were found to be statistically significant at $p \leq 0.05$.

From the above results, all the school factors studied were found to have a statistically significant influence on girls' performance in agriculture and therefore the third null hypothesis stating that school factors had no statistically significant influence on girls' performance in agriculture in Kirinyaga Central sub - county's public mixed day secondary schools was rejected. Girls in schools with adequate agriculture facilities would be expected to perform better in agriculture examination than girls in schools with inadequate agriculture facilities. The results of the study were consequently in agreement with the findings by Oghubu (2010) that one of the problems affecting girls' performance in agriculture is poor and inadequate agriculture facilities in schools. The results were also consistent with the findings by Ugborugbo and Akiri (2009) that inadequate facilities make good teaching and learning impossible. Adequate agriculture facilities such as the school farm or demonstration plots, farm tools and equipment, farm structures, livestock, text books and other agriculture resources would help turn otherwise theoretical agriculture lessons into demonstrations, practicals and projects that would go a long way in enhancing girls' knowledge and skills in agriculture and eventually improving their performance in agriculture. Teachers' academic qualifications were also found to have a statistically significant influence on girls' performance in agriculture, concurring with the findings by Akinsolu (2010) that high school girls learn more from teachers who hold bachelors or master's degree in the subjects they teach. Possession of high academic qualification is important since it was found to positively influence girls' performance in agriculture, in that the highly qualified teachers have vast knowledge of the subject matter. However, these results were inconsistent with the research findings of Daley and Kim (2010) that teachers' effectiveness is not well predicted by traditional qualifications such as advanced degrees. Similarly, teaching experience of the agriculture teachers was found to be a significant determinant of girls' performance in agriculture. The results were consistent with the findings by Robinson (2010) that there is a positive relationship between a teacher's experience and students' academic performance. This is probably because teachers' experience is expected to enhance their knowledge, skills and productivity. Experienced teachers could also be more innovative and creative in their lesson delivery. The results of the study therefore support assertions by The New Teacher Project [TNTP] (2010) that, while it is essential to hold high expectation for all teachers from their earliest days in the classroom, it is unrealistic to expect even talented novice teachers to meet the same expectations as more experienced teachers.

\section{Conclusions}

Based on the findings from this study, the following conclusions were made:

(i) Girls whose parents / guardians had higher levels of education performed better in agriculture than girls whose parents / guardians had lower levels of education.

(ii) Girls who received more parental support performed better in agriculture than girls who received little parental support. Parents or guardians supported their daughters through ways such as encouraging them to pass well in the subject, provision of personal effects to the girls, emphasizing the value of agriculture and education as a whole, provision of a conducive learning environment home and by guiding the girls when they were faced with education related problems.

(iii) Girls who were more involved in household chores ended up performing poorer in agriculture than girls who were less involved in the chores.

(iv) Teachers' academic qualifications had an influence on girls' performance in agriculture. Girls whose teachers have higher academic qualifications perform better in agriculture than girls whose teachers have lower academic qualifications.

(v) Teacher's experience influenced girls' performance in agriculture in that girls taught by teachers who were experienced ended up performing better.

(vi) Agriculture facilities are important in the teaching and learning of agriculture. Girls from schools having more agriculture facilities performed better in agriculture than girls from schools with fewer facilities. 


\section{Recommendations}

Based on the above conclusions, the following recommendations are made:

(i) Non - Governmental organizations (NGOs), churches, educationists, county governments and the elite in the society should organize forums where they educate the illiterate, the less educated, the less fortunate and the needy in the society on the value of education to their children and the society at large. They should also organize them into support groups where the value of education for their children is emphasized.

(ii) Parents and guardians should be sensitized by other education stakeholders such as teachers, churches and education officers on the need to support their daughters by among other ways, providing them with a conducive learning environment at home, provision of personal effects, offering them regular encouragement, guiding and counseling them, visiting their schools to discuss their performance with teachers, and emphasizing the need for learning and passing well in agriculture.

(iii) Parents and guardians should be guided by teachers on the need to have their daughters spend more time doing studies than engaging in household chores so that the girls perform better agriculture and also in other subjects.

(iv) School principals and boards of management of secondary schools should prioritize making agriculture facilities adequate in schools. They should consider agriculture facilities as important as facilities for learning the pure sciences. The government should fund the purchase and construction of agriculture facilities in secondary schools.

(v) Agriculture teachers with lower academic qualifications such as diploma should be encouraged to pursue degree programmes.

(vi) The government should strive to retain experienced agriculture teachers in secondary schools since they are more skilled than inexperienced teachers. The government could do this by remunerating agriculture teachers well and offering them other incentives such as promotions in their career life.

\section{Reference}

[1]. Abdallah, A. A. \& Noori, A. M. (2009). Parental involvement in students' mathematics achievement of fourth grade students at Alshaqab Independent Primary School for girls. Unpublished work. Retrieved on $22^{\text {nd }}$ may 2012 from http://www.education.gov.qa/research/samples/parental.pdf.

[2]. Achoka, K. S. J., Nafula, C. R \& Oyoo, O. M. (2013). Negative cultural influence on secondary school girl - students' academic achievement in Bungoma County, Kenya. Journal of Education and Curriculum Development Research (JECDR), 1 (2)

[3]. Adewumi, M. G., Olojo, O. J. \& Falemu, F. K. (2012). Roles of parent on the academic performance of pupils in elementary schools. International Journal of Academic Research in Business and Social Sciences, 2 (1).

[4]. Agwom, S. I. (2010). Improving the education industry towards meeting the Millennium Development Goals (MDGs): Perspective on the Motivational Factors. College of Education Gindiri.The Voice of Teachers, 1 (1).

[5]. Ajayi, O. K., \& Muriana, O. K. (2011). Parents' education, occupation and real mother's age as predictors of students' achievement in mathematics in some selected secondary schools in Ogun State, Nigeria. Academic Leadership Live:The Online Journal, 9 (1). Retrieved on $4^{\text {th }}$ April 2012 from http://www.academicleadership.org/article/print/parents-education-occupation-andreal-mothers-age-as-predictors-of-students"_achievement_in_mathematics

[6]. Akinsanya, O. O., Ajayi, K. O. \& Salomi, M. O. (2011). Relative effects of parents' occupation, qualification and academic motivation on students' achievement in senior secondary school mathematics in Ogun State. British Journal of Arts and Social Sciences, 3 (2).

[7]. Akinsolu, O. A. (2010). Teachers and students' academic performance in Nigerian secondary schools: Implications for Planning. Florida Journal of Educational Admistration\& Policy, 3 (2).

[8]. Ali, N., Jusoff, K., Ali, S., Mokhtar, N. \& Salamat, A. S. A. (2009). The factors influencing student's performance at UniversitiTechnologi MARA Kedah, Malaysia.Management Science and Engineering, 3 (4). Retrieved on $13^{\text {th }}$ April 2012 from http:/www.cscanada.net/index.php/mse/article/views/812

[9]. Antecol, H., Eren, O. \& Ozbeklik, S. (2012). The effect of teacher gender on student achievement in primary school: Evidence from a randomized experiment. IZA DP.No. 6453.

[10]. Ariyo, O. A. (2011). Gender differences and school location factors as correlate of secondary school students' achievement in physics. The 2011 Maui International Academic Conference.Maui, Hawaii, U.S.A 2011. Retrieved on $15^{\text {th }}$ june 2012 from conference, cluteoline.com/index.php/IAC/2011/HI/paper/.../80

[11]. Arko, D. A. (2013). The effects of home environment on academic performance of married female distance learners. Journal of Education and Practice, 4 (14).

[12]. Asikhia, O. A. (2010). Students' and teachers' perception of the causes of poor academic performance in Ogun State secondary schools (Nigeria): Implications for Counselling for National Development. European Journal of Social Sciences, 13 (2).

[13]. Atta, A. M. \& Jamil, A. (2012). Effects of motivation and parental influence on the educational attainment of students at secondary level. Academic Research International, 2 (3).

[14]. Bandura, A. (2006). Guide for constructing self - efficacy scales. Retrieved on $12^{\text {th }}$ may 2012 fromhttp://www.ravansanji.ir/files/ravansanji - ir/21655425BanduraGuide.pdf

[15]. Burton, L. J. \& Mazerolle, S. M. (2011). Survey instrument validity part 1: Principles of Survey Instrument Development and Validation in Athletic Training Education Research. Athletic Training Education Journal, 6 (1): $27-35$. Retrieved on $15^{\text {th }}$ may 2012from www.nataej.org/6.1/0601 - 027035.pdf

[16]. Beilock, S. L.,Gunderson, E. A., Ramirez, G. \& Levine, S. C. (2010). Female teachers' math anxiety affects girls' math achievement. Proceedings of the National Academy of Sciences, U.S.A, 107 (5): $1060-1063$.

[17]. Carrel, S. E., Marianne, E. P. \& James, E. W. (2010). Sex and Science: How professor gender perpetuates gender gap. Quarterly Journal of Economics, 125 (3): $1101-1144$

[18]. Chekaraou, I. \& Goza, A. N. (2013).Teachers implementing an educational policy and implications for pupils' (especially girls') access, performance and retention. Journal of International Cooperation in Education, 15 (3).

[19]. Chevalier, A., Harmon, C., O'sullivan, V. \& Walker, I. (2010). The impact of parental income and education on the schooling of their children. University College Dublin, 2010: Geary Institute.

[20]. Child Trends (2010). Parental expectation's for children's academic attainment. Retrieved on 6 $6^{\text {th }}$ May 2012 from www.childtrendsdatabank.org/alphalist? Q=node/366 
[21]. Chukwuemeka, O. (2013). Environmental influence on academic performance of secondary school students in Port Harcout local government area of Rivers State. Journal of Economics and Sustainable Development, 14 (12).

[22]. Cockfield, G. (2006).The impact of employment and domestic situations on student performance in introductory economics. International Journal of Business \& Management Education, 14 (1).

[23]. Coleman, J. S., Campbell, Q. E., Hobson, J. C., McPartland, J., Mood, M. A., Weinfeld, D. F., \& York, L. R. (1966). Equality of education opportunity. Washington, D.C.: U.S Government Printing Office.

[24]. Conway, S. K., \& Houtenville, A. (2008, May 27). Parental involvement strongly impacts student achievement. ScienDaily. Retrieved $10^{\text {th }}$ January 2012 , from http://www.sciencedaily.com/releases/2008/05/080527123852.htm

[25]. Crosby, H. (2011). Explaining achievement: Factors affecting Native American College Student Success.Unpublished paper. Retrieved on $20^{\text {th }}$ June 2012 from http://ecommons.txtaste.edu/arp/349

[26]. Cunningham, E. K. (2009). The effect of self - efficacy and psychological development on the factors that influence major changing behaviour. (Doctoral dissertation). Retrieved from Proquest Digital Dissertations. (AAT 3367821).

[27]. Dahar, A. M., Dahar, A. R., Dahar, T. R. \& Faize, A. F. (2011). Impact of teacher quality on the academic achievement of students at secondary stage in Punjab (Pakistan). European Journal of Social Sciences, 19 (1).

[28]. Daley, G. \& Kim, L. (2010). A teacher evaluation system that works. National Institute of Excellence in Teaching. Santa Monica, CA90401

[29]. Dawo, A. J. \& Simatwa, W. M. E. (2010). Opportunities and challenges for mixed day secondary school head teachers in promoting girl - child education in Kenya: A Case Study of Kisumu Municipality. Educational Research and Reviews, 5 (12): $730-741$. Retrieved on $10^{\text {th }}$ may 2012 from ttp.//www.academicjournal.org/ERR

[30]. Dee, S. T. (2007). Teachers and the gender gaps in student achievement. The Journal of Human Reasources, XLII.3

[31]. Dimbisso, S. T. (2009). Understanding female students' academic performance: An exploration of the situation in South Nations Nationalities and Peoples Regional State - Ethiopia. Unpublished Thesis. Retrieved $3^{\text {rd }}$ March 2012 from http://www.oaithesis.eur.nl/ir/repub/asset/6785/TADESSE_SHIFERAN_DIMBISSO_PPM_pdf_Latest_Version.pdf

[32]. Doss, C., Raney, T., Ariquenz, G., Croppenstedt, A., Gerosa, S., Lowder, S., Matuscke, I. \& Skoet, J. (2011). The role of women in agriculture. ESA Working Paper No. 11 - 02, F.A.O

[33]. Dubow, E. F., Boxer, P. \& Huesmann, R. L. (2009). Long - term effects of parent's education on children's educational and occupational success: Mediation by family interactions, child aggression and teenage aspirations. Merrill Palmer Q (Wayne State Univ Press).2009. Doi:10.1353/mpq.0.0030

[34]. Faize, A. F., \& Dahar, A. M. (2011).Effect of mother's level of education on secondary grade science students in Pakistan. Research Journal of International Studies - Issue 19.

[35]. Folashade, A. (2009). Teachers' attitude and gender factors as determinants of pupils' performance in primary science. African Research Review: An International Multi - Disciplinary Journal, 3 (1).

[36]. Garikai, W. B. (2010). Determinants of poor academic performance. Retrieved $17^{\text {th }}$ March 2012 from http://bongawellingtongarikai.articlebase.com//education-articles/determinants-of-poor-academic-performance-3659333.html.

[37]. Geckova, M. A., Tavel, P., Dijk, V. P. J., Thomas, A. \& Reijneveld, A. S. (2010). Factors associated with educational aspirations among adolescents: Cues to Counteract Socioeconomic Differences? BMC Public Health, 10 (154). DOI:10.1186/1471 - $2458-10$ -154 .

[38]. George, D. D., \& Mensah, D. K. D. (2010). Parental involvement in homework for children's academic success. A study in the Cape Coast Municipality. Academic Leadership Journal, 8 (2).

[39]. Glick, P., Randrianarisoa, C. J., \& Sahn, E. D. (2008). Family backgrounds, school characteristics and children cognitive achievement in Madagascar. Ithaca, NY: Cornell University.

[40]. Gliem, A. J. \& Gliem, R. R. (2003). Calculating, interpreting and reporting Cronbach's alpha reliability coefficient for Likert - type scales. Refereed paper: Gliem \& Gliem.

[41]. Hakijamii Kenya Education Rights (2009).

[42]. Hielat, Q. M. \& Al-Shabatat, M. A. (2012). Comparing academically gifted and non-gifted students' supportive environments in Jordan. International Interdisciplinary Journal of Education, 1 (6).

[43]. Hijazi, T. S. \& Naqvi, R. S. M. M. (2006). Factors affecting students' performance.A case study of private colleges. Banglandesh eJournal of Socialogy.3 (1).

[44]. Holmlund, H., Lindahl, M. \& Plug, E. (2011). The causal effect of parents' schooling on children's schooling: A comparison estimation methods. Journal of Economic Literature, 49(3):615-51. D01:10.1257/jel.49.3.615.

[45]. International Fund for Agricultural Development (2011).

[46]. Israel, D. G. (2009). Determining sample size. Publication No.PEOD 6. Retrieved on $20^{\text {th }}$ may 2012 from http://edis.ifas.ufl.edu

[47]. Jagero, O. N., Agak, J., \& Ayodo, M. T. (2010). An evaluation of home environmental factors affecting performance of boarding secondary school students in Kenya. Analytical Reports in International Education, 3 (1): 47-62. DOI : 10.3890/1542-3882-3-3

[48]. Jamali, K. (2009). The role of rural women in agriculture and its allied fields: A Case Study of Pakistan. European Journal of Social Sciences, 7 (3).

[49]. Jovanovic, M. L. (2008). Does parental influence hinder or foster students' academic progress? Non-Refereed Paper. Retrieved on $11^{\text {th }}$ May 2012 from http://www.aaee.com.au/conferences/papers/2008/aaee 08_submission_M3B1.pdf

[50]. Juma, A. L. S., Simatwa, W. M. E., \& Ayedo, O. M. T. (2011). Gender factor in performance of pupils in Kenya Certificate of Primary Education examination: A case study of Kombewa Division, Kisumu District. International Research Journals, 2 (3): 997 1005.

[51]. Kagume, D. W. (2010). A multiple case study of social cognitive influences on career choice in science, mathematics and technology among Kenyan women. Published Doctoral Thesis. Retrieved june 9, 2012from http://www.grin.com/en/doc/238050/a -

[52]. Kathuri, N. J. \& Pals, D. A. (1993).Introduction to educational research. EMC.Njoro, Kenya; Egerton University.

[53]. Katz, I., Kaplan, A., \& Buzukashvily, T. (2011, Aug. 31). Parents need an attitude adjustment to improve their children's homework motivation, experts say. ScienceDaily. Retrieved on $10^{\text {th }}$ January2012 from http://www.sciencedaily.com/released/2011/08/110831160042.htm

[54]. Kerlinger, F. (1975). Foundation of behavioral research: Education and Psychological Inquiry. Newyork.

[55]. Key, P. J. (1997). Research design in occupational education. Retrieved march 6, 2013 from http://www.okstate.edu/ag/agedcm4h/academic/aged5980a/Newpage18.htm

[56]. Kimani, N. E., \& Kombo, K. D. (2010). Gender and poverty reduction. A Kenyan context. Educational Research and Reviews, 5(1). Retrieved $4^{\text {th }}$ April 2012 from http://www.academicjournals.org/ERR2

[57]. Kothari, C. R.(1985). Research Methodology - Methods and Techniques. New Delhi; Willy Easternn Limited. 
[58]. Lai, F., Sadoulet, E. \& Janvry, A. (2009). The contributions of school quality and teacher qualifications to student performance: Evidence from a natural experiment in Beijing Middle Schools. Retrivedon $16^{\text {th }}$ May 2012 from are.berkeley.edu/esadoulet/papers/schooleffect.JHR.pdf

[59]. Lippman, C. P. (2010). Can the physical environment have an impact on the learning environment?

[60]. Metzler, J. \&Woessmann, L. (2010). The impact of teacher subject knowledge on student achievement: Evidence from Within Teacher Within - Student Variation. IZA DP No. 4999.

[61]. Mowla, A. A. A. S. (2009). Education and economic empowerment of women in Egypt.Working Paper No. 002. Cairo: Social Research Center.

[62]. Mugenda, O. (1999). Research method: Qualitative and Quantitative Approaches. Nairobi: Nairobi African Center for Technology.

[63]. Muola, J. M. (2010). A study of the relationship between academic achievement motivation and home environment among standard eight pupils. Education Research and Reviews, 5(5). Retrieved on $7^{\text {th }}$ April 2012 from http://www.academicjournals.org/ERR/PDF/pdf2010/May/Muola.pdf

[64]. Naderi, H., Abdullah, R., Aizan, T. H., Sharir, J., \& Kumar, V. (2009). Self esteem, gender and academic achievement of undergraduate students. Journal of American Scientific Research, ISSN 1450 - 223X Issue 3; Euro Journals Publishing; 2009.

[65]. Netemeyer, R. G., Bearden, W. O. \& Sharma, S. (2003). Scaling Procedures: Issues and Applications. London: Sage; 2003.

[66]. Neugebauer, M., Helbig, M. \& Landmann, A. (2010). Can the teacher's gender explain the 'Boy Crisis' in educational attainment? Arbeitspapiere - Working Papers, Nr. 133.

[67]. Ntumwa, E. M. \& Rwambili, G. E. (2013). School dropout in community secondary schools: A Case of Nyamilama Secondary School - Mwanza Tanzania. International Journal of Science and Technology, 2 (10).

[68]. Nuthana, P. G. (2007). Gender analysis of academic achievement among high school students (Unpublished Masters Thesis). University of Agricultural Sciences, Dharwad. Retrieved on $2^{\text {nd }}$ April 2012 from www.etd.uasd.edu/ft/th9534.pdf

[69]. Offorma, C. G. (2009). Girl-child education in Africa.

[70]. Oghuvbu, P. E. (2008). Absenteeism and lateness among secondary school students in Nigeria: Profiling causes and solutions. Academic Leadership Live: The Online Journal, 6(3). Retrieved $13^{\text {th }}$ April 2012 from www.academicleadership.org/ISSNi5337812 6.3-559.pdf

[71]. Oghuvbu, P. E. (2010). Attendance and academic performance of students in secondary school: A Correlational Approach. Stud Home CommSci, 4 (1): $21-25$

[72]. Omenge, B. N., \& Nasongo, J. W. (2010). Effect of socialization with regard to gender roles on students' academic achievement in secondary schools in Kisii Central District, Kenya. Current Research Journal of Social Sciences, 2(6). Retrieved from http://www.maxwellsci.com/print/crjss/v2-327-333.pdf

[73]. Odinga, I. (2011). Proceeding's From the Commission on the Status on Women. Fifty-Fifth Session. $6^{\text {th }} \& 7^{\text {th }}$ meetings. UN: Education is Gateway to Unlocking Women's Potential. Retrieved on $6^{\text {th }}$ March 2012 from http://www.un.org/news/press/docs//2011/wom1843.doc.htm

[74]. Opolot-Okurut, C., \& Oluka, S. (2008). Performance in primary education in the Teso Region: An exploratory study. Kampala, Uganda: Final Report Submitted to the Uganda National Commission for UNESCO. Retrieved from http://www.unesco_uganda.ug/index.php?option=com_docman\&task=..

[75]. Owoeye, S. J., \& Yara, O. P. (2011). School facilities and academic achievement of secondary school agricultural science in Ekiti, Nigeria. Asian Social Science, 7 (7). Doi : 10.5539/ass.v7n7p64

[76]. Public Health Action Support Team [PHAST] (2011). Parametric and non - parametric tests for comparing two or more groups. Retrieved on $1^{\text {st }}$ July 2013 from www.healthknowledge.org.uk/public-health-textbook/research-methods/lb-statisticalmethods/parametric-nonparametric-tests

[77]. Raychaudhuri, A., Debnath, M., Sen, S \& Majumder, G. B. (2010). Factors affecting students' academic performance. A case study in Agartala Municipal Council Area. Bangladesh e-Journal of Sociology, 7 (2). Retrieved from www.bangladeshsociology.org/BEJS7.2-factorsAffecting Students-pdf

[78]. Rice, K. J. (2010). The impact of teacher experience: Examining the evidence and policy implications. Center for Analysis of Longitudinal Data in Education Reseach.

[79]. Robinson, I. D. (2009). Teacher quality as a factor of student achievement: How does the type of teacher certification correlate with student mathematic achievement? Retrieved on $15^{\text {th }}$ june 2012 from www.pdkintl.org/member/docs/R-Teacher-Quality.pdf

[80]. Saito, M., \& Capelle, V. F. (2009). Proceedings From the International Symposium on Quality Education for All - Approches to Monitoring and Improving the Quality of Education. Retrieved from www.sacmeq.org/downloads/papers/saito - VanCapelle2009_Approaches-to-monitoring-the Quality-of-Education-in-Developing- Countries.pdf

[81]. Satyavathi, T. C., Bharadwaji, C. \& Brahmanand, P. S. (2010). Role of farm women in agriculture: Lessons learned. Gender, Technology and Development, 14 (3): 441 - 449. DOI: 10.1177/097185241001400308

[82]. Shilubane, N. H. (2009). Chapter 3 research methodology - Unisa Institutional Repository. Retrieved on $4^{\text {th }}$ march 2013 from uir.unisa.ac.2a/bitstream/handle/10500/1450/04Chapter3.pdf

[83]. Sichone, C. (2011, August 8). Zambia: Celebrating courage, character on Nelson Mandela. Times of Zambia. Retrieved on $2^{\text {st }}$ May 2012 from http://allafrica.com/stories/201108082260.html

[84]. The McGraw-Hill Companies. (2001). Marketing research and database development. Retrieved on $4^{\text {th }}$ march 2013 from http://www.mhhe.com/business/marketing/hair2e/student_center/ch_09/summary.mhtml

[85]. The New Teacher Project. (2010). Teacher evaluation 2.0. Retrieved on $2^{\text {nd }}$ march 2013 from tntp.org/assets/documents/TeacherEvaluation-Oct10F.pdf? files/Teacher-Evaluation-Oct10F.pdf

[86]. Turocy, P. S. (2002). Survey research in athletic training: The Scientific Method of Development and Implementation. Journal of Athletic Training, 37 (suppl 4): S174 - S179.

[87]. Ugborugbo, M. N. \& Akiri, A. A. (2009). Teachers' effectiveness and students' academic performance in public secondary schools in Delta State, Nigeria. Stud Home Sci, 3 (2): $107-113$.

[88]. Uwaifo, O. V. (2008). The effects of family structure and parenthood on the academic performance of Nigerian University students. Stud Home CommSci, 2 (2). Retrieved $28^{\text {th }}$ May 2012 from http://www.krepublishers.com/02_Journals/S-Hcs/HCS-02-0000-08-web/HCS-02-2-087-08-abst-Text/HCS-02-2-121-08-056-Uwaifo-v-o/HCS-02-2-121-08-05-uw

[89]. Verveer, M. (2011). The vital role of women in agriculture and rural development. F.A.O. Retrieved on $20^{\text {th }}$ june 2012 fromwww.state.gov/s/gwi/rls/rem/2011/167899.htm 